Old Dominion University

ODU Digital Commons

CCPO Publications

Center for Coastal Physical Oceanography

1995

\title{
Transport, Potential Vorticity, and Current/ Temperature Structure Across Northwest Providence and Santaren Channels and the Florida Current Off Cay Sal Bank
}

Kevin D. Leaman

Peter S. Vertes

Larry P. Atkinson

Old Dominion University, latkinso@odu.edu

Thomas N. Lee

Peter Hamilton

See next page for additional authors

Follow this and additional works at: https://digitalcommons.odu.edu/ccpo_pubs

Part of the Oceanography Commons

\section{Repository Citation}

Leaman, Kevin D.; Vertes, Peter S.; Atkinson, Larry P.; Lee, Thomas N.; Hamilton, Peter; and Waddell, Evans, "Transport, Potential Vorticity, and Current/Temperature Structure Across Northwest Providence and Santaren Channels and the Florida Current Off Cay Sal Bank" (1995). CCPO Publications. 303.

https://digitalcommons.odu.edu/ccpo_pubs/303

\section{Original Publication Citation}

Leaman, K. D., Vertes, P. S., Atkinson, L. P., Lee, T. N., Hamilton, P., \& Waddell, E. (1995). Transport, potential vorticity, and current/ temperature structure across Northwest Providence and Santaren Channels and the Florida Current off Cay Sal Bank. Journal of Geophysical Research: Oceans, 100(C5), 8561-8569. doi:10.1029/94jc01436 
Authors

Kevin D. Leaman, Peter S. Vertes, Larry P. Atkinson, Thomas N. Lee, Peter Hamilton, and Evans Waddell 


\title{
Transport, potential vorticity, and current/temperature structure across Northwest Providence and Santaren Channels and the Florida Current off Cay Sal Bank
}

\author{
Kevin D. Leaman,' Peter S. Vertes,' Larry P. Atkinson, ${ }^{2}$ Thomas N. Lee,' \\ Peter Hamilton, ${ }^{3}$ and Evans Waddell ${ }^{3}$
}

\begin{abstract}
Currents and temperatures were measured using Pegasus current profilers across Northwest Providence and Santaren Channels and across the Florida Current off Cay Sal Bank during four cruises from November 1990 to September 1991. On average, Northwest Providence $(1.2 \mathrm{~Sv})$ and Santaren $(1.8 \mathrm{~Sv})$ contribute about $3 \mathrm{~Sv}$ to the total Florida Current transport farther north (e.g., $\left.27^{\circ} \mathrm{N}\right)$. Partitioning of transport into temperature layers shows that about one-half of this transport is of " $18^{\circ} \mathrm{C}$ " water $\left(17^{\circ} \mathrm{C}-19.5^{\circ} \mathrm{C}\right)$; this can account for all of the "excess" $18^{\circ} \mathrm{C}$ water observed in previous experiments. This excess is thought to be injected into the $18^{\circ} \mathrm{C}$ layer in its region of formation in the northwestern North Atlantic Ocean. Due to its large thickness, potential vorticities in this layer in its area of formation are very low. In our data, lowest potential vorticities in this layer are found on the northern end of Northwest Providence Channel and are comparable to those observed on the eastern side of the Florida Current at $27^{\circ} \mathrm{N}$. On average a low-potential-vorticity $18^{\circ} \mathrm{C}$ layer was not found in the Florida Current off Cay Sal Bank.
\end{abstract}

\section{Introduction}

Because of its importance to the overall general circulation of the North Atlantic Ocean, the Florida Current has been the subject of numerous experimental studies over the years. Early direct transport measurements using dropsondes [Schmitz and Richardson, 1968; Richardson et al., 1969; Niiler and Richardson, 1973] showed that at the latitude of Miami the mean current transport was about 29.5 Sv $\left(1 \mathrm{~Sv}=10^{6} \mathrm{~m}^{3} \mathrm{~s}^{-1}\right)$. Cross sections were obtained at other latitudes as well. Later (1974) dropsonde data [Brooks and Niiler, 1977; Brooks, 1979] were combined with those obtained at a different latitude by Niiler and Richardson [1973] to estimate important mean and perturbation quantities such as perturbation kinetic and potential energies in the Florida Current

More recently, in excess of 2 years of current meter, Pegasus acoustic current profiler, electromagnetic cable, and other data were obtained on a section across the Florida Current at $27^{\circ} \mathrm{N}$ [Molinari, 1983; Mayer et al., 1984; Molinari et al., 1985a, b; Lee et al., 1985; Larsen and Sanford, 1985; Maul et al., 1985; Schott and Zantopp, 1985; Leaman et al., 1987; Johns and Schott, 1987; Leaman and Molinari, 1987; Lee and Williams, 1988; Schott et al., 1988]. These data suggested a mean transport at $27^{\circ} \mathrm{N}$ of about $31.7 \mathrm{~Sv}$.

Subsequent to the above work, a more detailed analysis of

\footnotetext{
'Rosenstiel School of Marine and Atmospheric Science, University of Miami, Miami, Florida.

${ }^{2}$ Center for Coastal Physical Oceanography, Old Dominion University, Norfolk, Virginia.

${ }^{3}$ Science Applications International Corporation, Raleigh, North Carolina.
}

Copyright 1995 by the American Geophysical Union.

Paper number $94 \mathrm{JC} 01436$.

0148-0227/95/94JC-01436\$05.00 the Florida Current/Gulf Stream cross-stream structure was carried out using Pegasus profiler data at $27^{\circ} \mathrm{N}$ as well as at $29^{\circ} \mathrm{N}$ and off Cape Hatteras [Leaman et al., 1989]. In this work the current transport at these locations was partitioned into $2.5^{\circ} \mathrm{C}$ temperature bins in order to resolve transport, potential vorticity, and layer thickness as a function of temperature. Such a resolution permits one to observe clearly certain features of the flow. For example, at $27^{\circ} \mathrm{N}$ the presence of $18^{\circ} \mathrm{C}$ water on the right side of the channel (looking downstream) of presumed North Atlantic origin could be easily detected, although its origins could not. More recently, Schmitz and Richardson [1991] have used these and other data to separate Florida Current transport into different source regions (in particular, water deriving from North Atlantic versus South Atlantic sources).

One important question left unanswered by the above experiments was the potential contributions to Florida Current transport by its subsidiary channels, the most important of which are Northwest Providence Channel (NWPC), Santaren Channel (SC) and Old Bahama (and Nicholas) Channel (Figure 1). The only direct current measurements using dropsondes in NWPC, made during the period March 20-22, 1966, indicated a possible inflow to the Florida Current of 1.5-2.5 Sv [Richardson and Finlen, 1967]. However, virtually no direct current measurements have been reported for SC or Old Bahama (OBC) Channels. Pilot charts [Smith, 1940 ] indicate that surface currents in OBC typically set to the northwest but can be quite variable. Similarly, presentday navigation charts indicate that surface currents in the eastern half of SC are typically to the northwest (toward the Florida Current).

To obtain more direct current data in these subsidiary channels and for other reasons, a 1-year experiment was initiated in November 1990 to deploy Pegasus current profiler, current meter, and hydrographic sections across these 


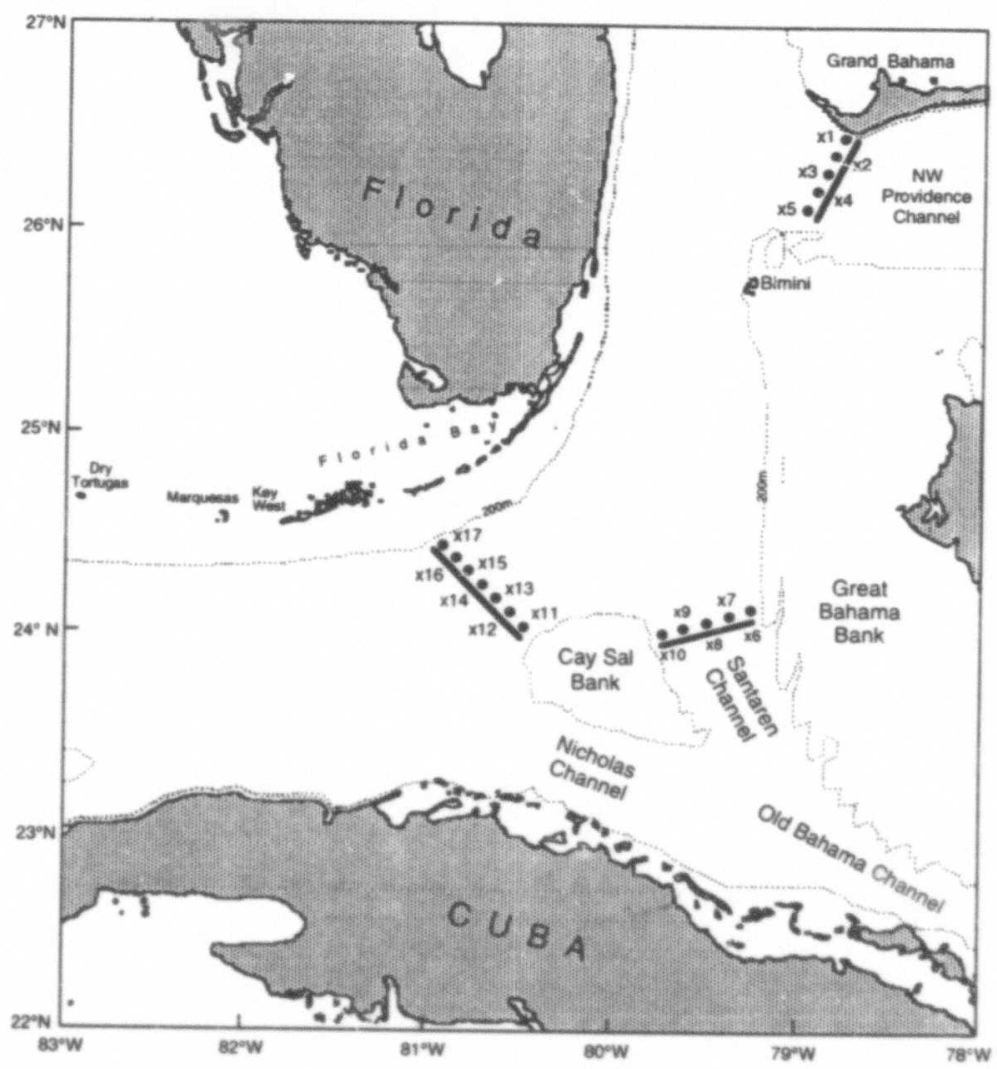

Figure 1. Locations of Pegasus sections during the SFPOFS experiment: Northwest Providence Channel (stations X1-X5); Santaren Channel (stations X6-X10); section "'B" (stations X11-X17).

subsidiary channels as well as at various latitudes across the Florida Current itself (Straits of Florida Physical Oceanographic Field Study (SFPOFS) [Science Applications International Corporation (SAIC), 1992].

This paper presents an analysis of Pegasus sections ob tained across SC and NWPC and across the Florida Current between Cay Sal Bank and the Florida Keys during four cruises from November 1990 to September 1991. Related observations from $\mathrm{OBC}$ and the Straits of Florida proper are presented in two companion papers [Atkinson et al., this issue; Lee et al., this issue]. A basic description of the Pegasus component of this experiment is given in section 2. In sections 3 and 4 the average cross-stream current and temperature structure, both in physical space and partitioned into temperature bins, are presented in order to compare these observations to previous results at other latitudes in the Florida Current/Gulf Stream. Finally, some conclusions are presented in the last section.

\section{The SFPOFS Study-Pegasus Observations}

Dates for the four Pegasus cruises made as part of SF. POFS are listed in Tablc 1. Locations of all stations are shown in Figure 1. During cruise I the bottom acoustic transponders at all stations were deployed with the exception of X17 (at the northwestern end of section "B"), which was not deployed until cruise II.

On each of the four cruises, repeated Pegasus sections were made along each line. (Unfortunately, we were unable to visit NWPC during cruise III, owing to some ship problems.) To reduce the effects of tidal biasing, drops at each station in NWPC and SC were repeated at one-quarter periods of the semidiurnal tide. At NWPC where the tide is mainly semidiurnal, an average of such drops over one semidiurnal period will significantly reduce the tidal signal. At SC where the tide is expected to be mixed semidiurnal/ diurnal, such drops were averaged over one diurnal (i.e., two semidiurnal) periods. Because of its length (and number of stations) such a sampling scheme was not possible along section "B." As a result, in this case as many repeated complete sections (usually four) as time permitted were made during each cruise and averaged.

Beyond the above considerations, Pegasus data were processed in a manner essentially identical to that used in previous experiments [Leaman et al., 1987] (hereinafter LMV87). In particular, all drops were made to within 2-3 m of the bottom, and profile data were interpolated to $10 \mathrm{~m}$ vertical depth increments. Stations were surveyed in a way similar to LMV87, with the exception that the Global Posi-

Table 1. SFPOFS Pegasus Cruises

\section{Dates}

Cruise 1

Cruise II

Cruise III

Cruise IV
November 19-29, 1990

February 23-March 2, 1991

May 28-June 2, 1991

September 6-12, 15-21, 1991 
tioning System was used for all transponder surveys, rather than the less-accurate Loran-C used in previous work in the region.

\section{Average Cross Sections and Transports}

The average cross sections shown in this section are derived from global (four-cruise) averages of the data from each section. It should be kept in mind, however, that data for NWPC were not obtained during cruise III.

For NWPC and SC the downstream transport is aligned approximately with the normal to the section. Therefore in these two cases velocities have been resolved into components normal to and parallel to the section orientations $\left(028^{\circ} \mathrm{T}\right.$ and $070^{\circ} \mathrm{T}$ for the NWPC and SC sections, respectively). The appropriate coordinate rotation is less apparent for section "B." Although this section (toward $129^{\circ} \mathrm{T}$ ) is approximately normal to the boundary at the eastern (Cay Sal) end, the section as a whole is tilted relative to the mean downstream axis of the topography (Figure 1). As a result, most sections show a significant flow component parallel to the section (toward Cay Sal Bank). For this reason, on section " $B$ " we have projected velocity components parallel and perpendicular to a direction defined for each cruise by the average of those stations (typically stations X12-X14) having the largest transport/unit width [Halkin and Rossby, 1985; Leaman et al., 1989]. The "downstream" flow as determined in this procedure is on average about $27^{\circ}$ to the right of the normal to section "B" $\left(039^{\circ} \mathrm{T}\right)$, or $066^{\circ} \mathrm{T}$. Downstream layer transports and potential vorticities (section 4) have also been computed for section " $B$ " using the coordinate definition procedure outlined above on a percruise basis. In all cases a positive component is in the direction indicated by the figure legend.

\section{Northwest Providence Channel}

Average velocity components normal and parallel to this section, and temperature, are presented in Figures $2 \mathrm{a}, 2 \mathrm{~b}$, and $2 \mathrm{c}$, respectively. The average downstream flow is characterized by a broad layer of inflow to the Florida Current below about $80-100 \mathrm{~m}$ depth, with flow away from the Florida Current at shallower depths in the northern half of the channel. Although cross-channel velocities are in general small, it is clear that the upper $100 \mathrm{~m}$ has a large average flow away from Grand Bahama Island in the northern part of the section. This upper layer "retrograde" (i.e., away from the Florida Current) flow has been observed previously [Leaman and Molinari, 1987] on the eastern side of the Straits of Florida at $27^{\circ} \mathrm{N}$ where it was argued to be a resuit of flow in the surface layer impinging upon Little Bahama Bank. The average current structure here is in reasonable agreement with that observed in current meter data if it is kept in mind that the thin surface layer of "retrograde flow" was typically above the upper-level current meters and thus would not have been observed. Average temperature contours (Figure 2c) reveal only a weak baroclinicity (downward tilting of isotherms producing a vertically sheared geostrophic horizontal current) below about $200 \mathrm{~m}$ depth; however, a thick layer of $18^{\circ} \mathrm{C}$ water (see section 4 below) is present over most of the channel.
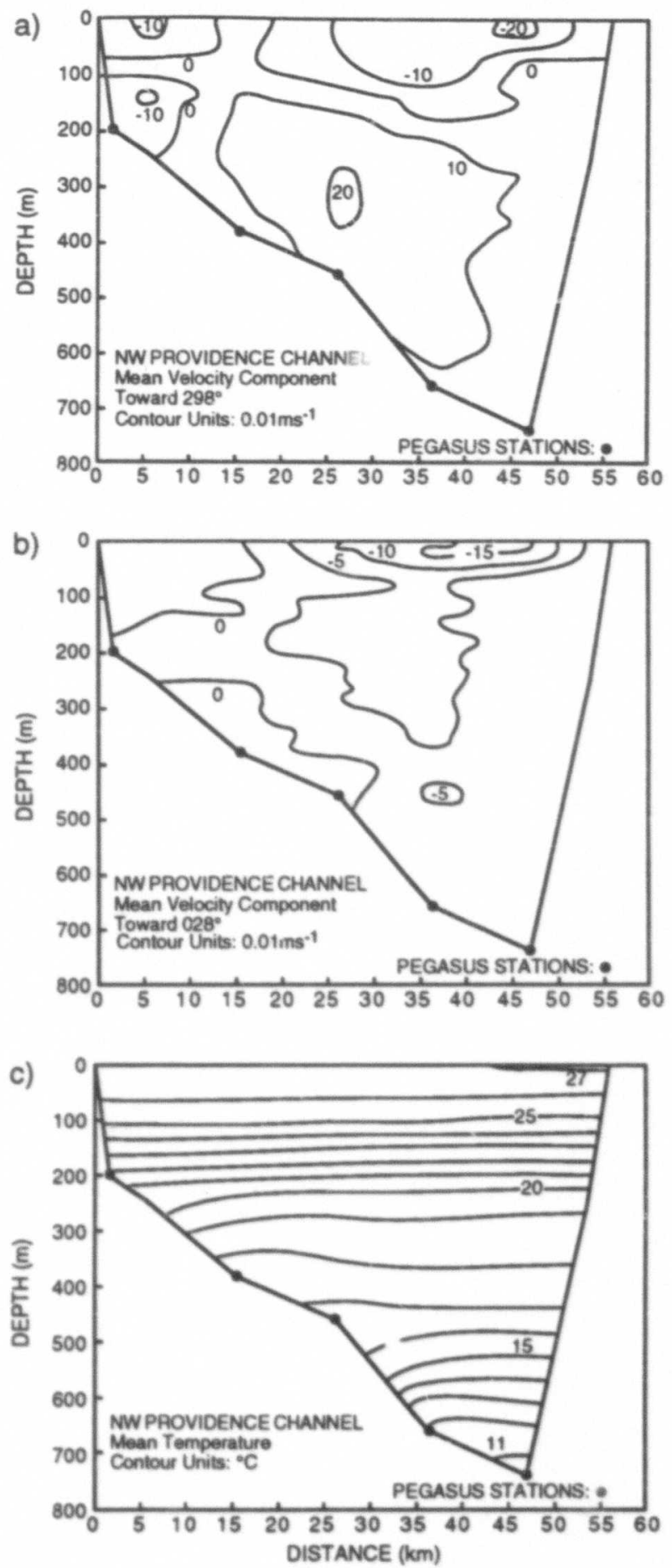

Figure 2. Contours of average (a) downstream and (b) cross-stream velocity components, and (c) temperature for the Northwest Providence Channel section.

\section{Santaren Channel}

The corresponding average plots for SC (Figures 3a, 3b, and 3c) show that, as with NWPC, the largest velocity components are directed along the channel toward the Florida Current (Figure 3a), with a relatively weak crosssection flow (Figure 3b). Also similar to NWPC, the Florida 

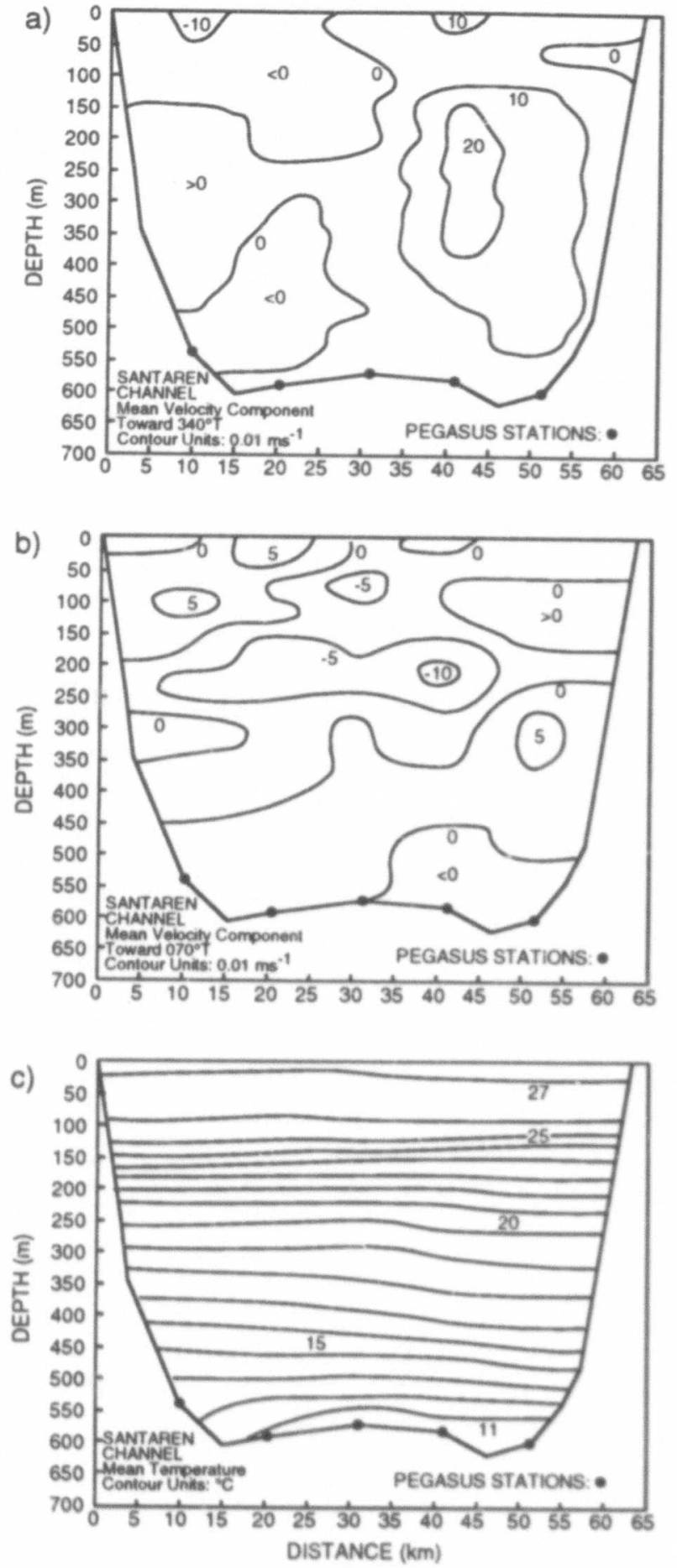

Figure 3. As in Figure 2, but for Santaren Channel.

Current inflow is mainly concentrated in the right half of the channel looking downstream. Depth averaged flows nearer Cay Sal Bank are weak and are directed away from the Florida Current. The downstream velocities are similar to those inferred from current meter velocities [Lee et al., this issue]. In particular, maximum downstream velocities $(\sim 20$ $\mathrm{cm} \mathrm{s}^{-1}$ ) are found on the eastern side of SC at depths of $300-400 \mathrm{~m}$. The average temperature structure (Figure $3 \mathrm{c}$ ) is relatively flat but does exhibit a small baroclinicity between stations $\mathrm{X8}$ and $\mathrm{X} 7$ (Figure 1). A relatively thinner layer of $18^{\circ} \mathrm{C}$ water than observed in NWPC is present in SC, mostly concentrated in the eastern half of the channel.

\section{Section "B" (Florida Current)}

Although the "downstream" and "cross-stream" velocity components on this section (Figures $4 \mathrm{a}$ and $4 \mathrm{~b}$ ) are shown as directed toward $066^{\circ} \mathrm{T}$ and $156^{\circ} \mathrm{T}$, respectively, it should be kept in mind that the downstream direction was determined for each cruise using the stations with the largest transports/ unit width, as indicated in the previous section. The average downstream direction was $27^{\circ}$ to the right of the section normal; however, individual cruises showed departures of up to $\pm 10^{\circ}$ from this average.

Average maximum downstream surface velocities are comparable to those seen farther north (LMV87), but the surface core of the Florida Current on this section is on average displaced much farther offshore. The cross-stream component (Figure 4b) shows convergent flow into the downstream surface core with maximum velocities near Cay Sal Bank. In fact, greatest downstream transports/unit width are found near this feature (stations X12-X14). Average temperatures (Figure $4 \mathrm{c}$ ) are qualitatively similar to those observed at $27^{\circ} \mathrm{N}$. However, there appears to be little indication of a thick $18^{\circ} \mathrm{C}$ layer at section "B" (see next section).

\section{Transports}

Cruise-averaged absolute transports for each cruise and section are tabulated in Table 2. For NWPC and SC a positive transport is directed toward $298^{\circ} \mathrm{T}$ and $340^{\circ} \mathrm{T}$, respectively (i.e., toward the Florida Current). For section "B" transports for each cruise were computed using the section projection procedure described above. In other respects the method was identical (with extrapolation to the channel side walls) to that used in LMV87.

The overall total average transport of the three sections is $28.7 \mathrm{~Sv}$ (29.1 Sv if we replace the missing NWPC value by its average over the remaining three cruises). This average value is comparable to values reported previously for the Florida Current (e.g., 29.5 Sv [Niiler and Richardson, 1973]) but slightly less than the average transport at $27^{\circ} \mathrm{N}$ of $31.7 \mathrm{~Sv}$ (LMV87). Part of this discrepancy may arise from the questionable extrapolation required to the northwest of station $\mathrm{X} 17$ on section "B." Nevertheless, the average transports of NWPC $(\sim 1.2 \mathrm{~Sv})$ and SC $(\sim 1.8 \mathrm{~Sv})$ can contribute significant inflow ( $\sim 3 \mathrm{~Sv}$ ) to the Florida Current.

It is not possible to assign meaningful and quantitative confidence intervals to these mean transport values from only four cruises. However, other independent data support our resuits [SA/C, 1992]. For example, synthetic transport time series generated from current meter arrays at each section show that transport variability across NWPC was rather small (a few Sverdrup) and that each Pegasus cruise took place during a period of "nonanomalous" transport.

The situation in SC and on section "B" is more complex in that during the experiment there were a number of short (about 2-week) events during which transport fluctuations across these two sections are highly negatively correlated [SAIC, 1992]. Cruise IV took place near the end of one such event, so that Santaren transport was anomalously low; however, cruise I was done during the opposite phase of a 
similar event, giving an anomalously high transport and on average tending to cancel the transport anomaly. It is also of interest to note that the overall trend of decreasing total transport seen in the Pegasus sections during the experiment is reproduced in the current meter data.
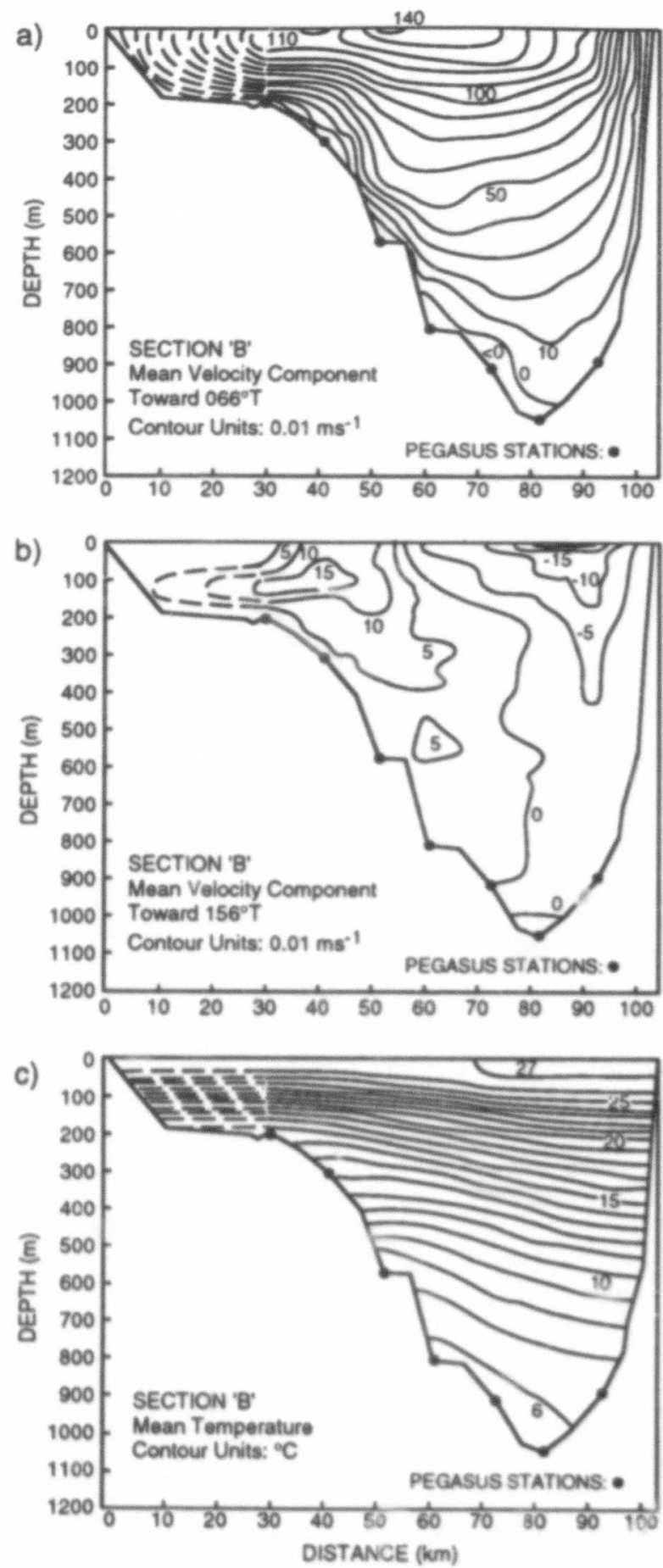

Figure 4. As in Figure 2, but for section "B" (Florida Current).
Table 2. Cruise-Averaged Absolute Transports

\begin{tabular}{lcc}
\hline Section & & $\begin{array}{c}\text { Transport, } \\
\times 10^{6} \mathrm{~m}^{3} \mathrm{~s}^{-1}\end{array}$ \\
NWPC & Cruise I & 1.77 \\
SC & & 6.53 \\
B & & 24.08 \\
Total & & 32.38 \\
& Cruise II & \\
NWPC & & -1.06 \\
SC & & 2.74 \\
B & & 27.73 \\
Total & & 29.41 \\
& & \\
NWPC & Cruise III & - \\
SC & & -0.98 \\
B & & 26.99 \\
Total & & 27.97 \\
& & \\
NWPC & Cruise IV & 2.92 \\
SC & & -3.01 \\
B & & 25.30 \\
Total & & 25.21 \\
\hline
\end{tabular}

\section{Transport, Potential Vorticity, and Layer Thickness in $2.5^{\circ} \mathrm{C}$ Temperature Bins}

To compare the cross-stream structure of these sections to previous results for the Florida Current/Gulf Stream, we have computed layer transports, potential vorticities, and thicknesses over $2.5^{\circ} \mathrm{C}$-thick temperature layers with boundaries at $\ldots, 22.0,19.5,17.0, \ldots{ }^{\circ} \mathrm{C}$. For each Pegasus station, layer thickness is computed as the vertical distance between any two adjacent temperature boundaries given above. For example, the $18^{\circ} \mathrm{C}$ layer is contained within the boundaries of $17.5^{\circ} \mathrm{C}$ to $19.0^{\circ}$. Transport in a $2.5^{\circ} \mathrm{C}$ layer between any adjacent pair of Pegasus stations is computed by trapezoidal integration of across-section (or "downstream" in the case of section B) velocities between the two stations and over the vertical distances defined at each of the stations by the temperature interval. Finally, layer potential vorticity is computed using (in addition to the local Coriolis parameter) the average layer thickness of the two stations and the horizontal gradient of across-section (or downstream) velocity (averaged over the layer thickness) between the two stations. The reader is referred to section 4 and Figure 5 of Leaman et al. [1989] for a more precise definition and discussion of these quantities, including a comparison of the layer potential vorticity defined above to others found in the literature. As noted in this work, at $27^{\circ} \mathrm{N}$ several characteristics of layer thickness, potential vorticity and transport distinguish the Florida Current. First, in the eastern $20-30 \mathrm{~km}$ of the channel a clearly defined $18^{\circ} \mathrm{C}$ layer is present with potential vorticities less than about $5 \times 10^{-7}$ $\mathrm{m}^{-1} \mathrm{~s}^{-1}$. In fact, comparison to sections made farther north [Leaman et al., 1989] shows that this value is a good indicator for $18^{\circ} \mathrm{C}$ water of North Atlantic origin. Second, the $10 \times 10^{-7} \mathrm{~m}^{-1} \mathrm{~s}^{-1}$ potential vorticity contour is a good delimiter for the cyclonic portion of the Florida Current. Although values can exceed $5 \times 10^{-7} \mathrm{~m}^{-1} \mathrm{~s}^{-1}$ near the western bound $y$ at $27^{\circ} \mathrm{N}$, it is probable that bottom friction plays a role at $29^{\circ} \mathrm{N}$ [Leaman et al., 1989], where the western boundary was farther away. The maximum values of 


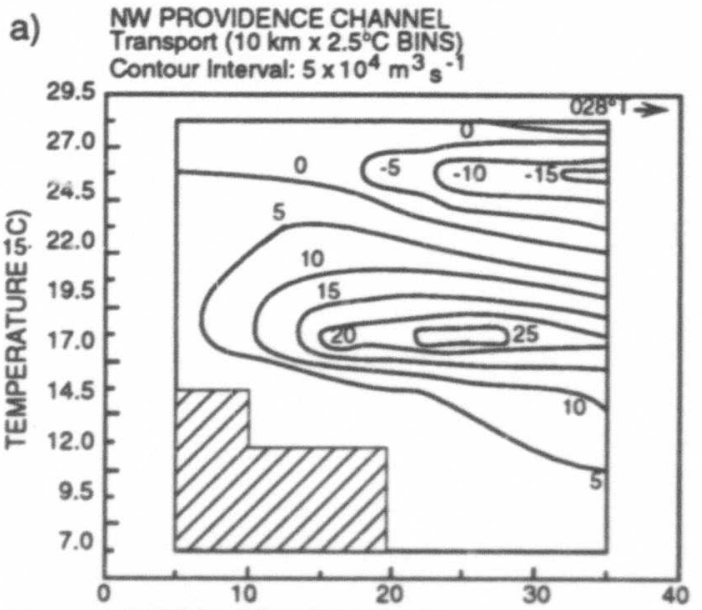

b) NW PROVIDENCE CHANNEL

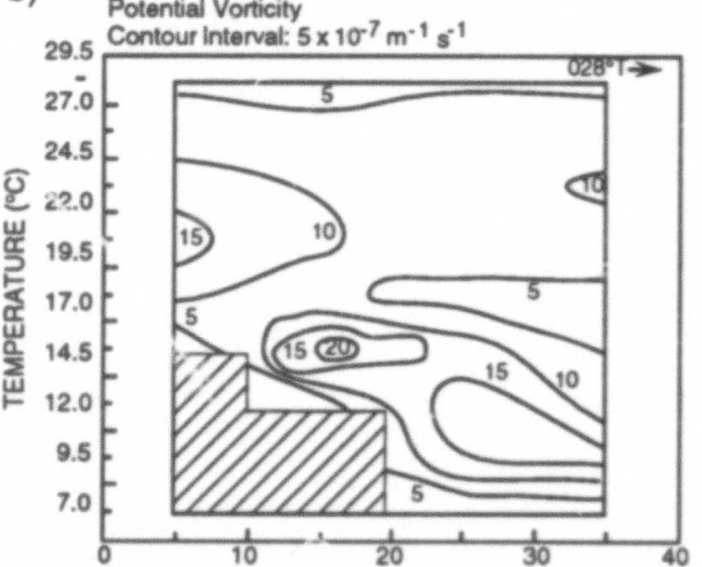

c) NW PROVIDENCE CHANNEL

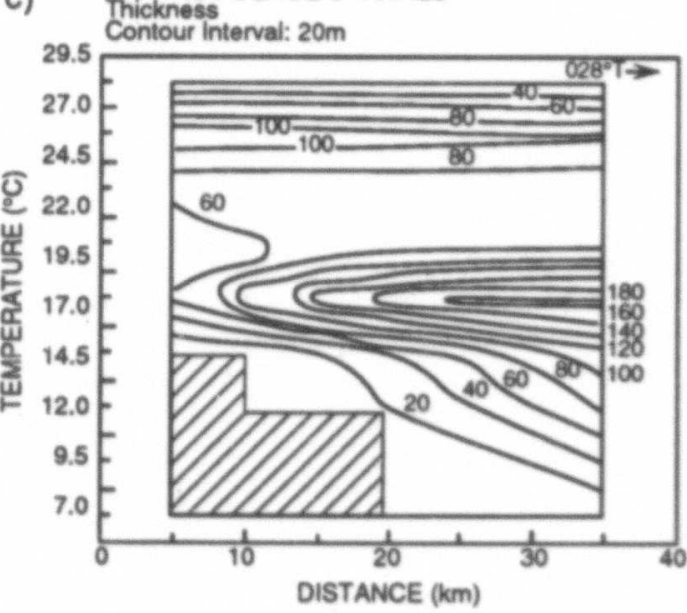

Figure 5. Contours of average (a) $2.5^{\circ} \mathrm{C}$-layer transport, (b) potential vorticity, and (c) thickness for the Northwest Providence Channel section.

$30-35 \times 10^{-7} \mathrm{~m}^{-1} \mathrm{~s}^{-1}$ observed are probably more typical of the Florida Current.

\section{Northwest Providence Channel}

The most obvious feature of the layer transport, potential vorticity, and thickness contours (Figures $5 \mathrm{a}, 5 \mathrm{~b}$, and $5 \mathrm{c}$, respectively) on this section is the clearly identifiable, thick layer of low-potential-vorticity $\left(<5 \times 10^{-7} \mathrm{~m}^{-1} \mathrm{~s}^{-1}\right) 18^{\circ} \mathrm{C}$ water in the northern half of the channel (Figures $5 \mathrm{~b}$ and $5 \mathrm{c}$ ). In fact, most of the inflow to the Florida Current across this section (Figure 5a) is concentrated in this layer, and the $5 \times$ $10^{-7} \mathrm{~m}^{-1} \mathrm{~s}^{-1}$ potential vorticity contour extends approximately the same distance into the current from the righthand boundary as was observed at $27^{\circ} \mathrm{N}$ [Leaman et al., 1989].

\section{Santaren Channel}

Here inflow to the Florida Current is again confined to the right half of the channel and is maximum in the $18^{\circ} \mathrm{C}$ layer (Figure 6a). A secondary transport maximum appears at about $26^{\circ} \mathrm{C}$, but this layer is not reproduced in either the potential vorticity or thickness contours (Figures $6 \mathrm{~b}$ and $6 \mathrm{c}$ ). In contrast to NWPC, however, except for a small region at the extreme western end of this section the lowest potential vorticities $\left(<5 \times 10^{-7} \mathrm{~m}^{-1} \mathrm{~s}^{-1}\right)$ observed farther north in NWPC and the Florida Current at $27^{\circ} \mathrm{N}$ are absent, even in the high-transport layer against Great Bahama Bank.

\section{Section "B"}

Compared to the structure of layer transport, potential vorticity, and thickness seen in the previous two sections and in the Florida Current at $27^{\circ} \mathrm{N}$ [Leaman et al., 1989], at least two aspects of the structure observed in section " $\mathrm{B}$ " (Figures 7a-7c) are different. First, there is no evidence for the $5 \times 10^{-7} \mathrm{~m}^{-1} \mathrm{~s}^{-1}$ contour of low potential vorticity $18^{\circ} \mathrm{C}$ water on this section, nor is there any indication, in contrast to the two sections described previously, of any increased transport or thickness in this layer. Second, maximum values of layer potential vorticity here do not exceed $\sim 25 \times$ $10^{-7} \mathrm{~m}^{-1} \mathrm{~s}^{-1}$, in contrast to values $30-35 \times 10^{-7} \mathrm{~m}^{-1} \mathrm{~s}^{-1}$, found away from boundaries farther north.

\section{Discussion}

We have used the "velocity/temperature" perspective given by these data to evaluate the contributions to total Florida Current transport on an annual average from two subsidiary channels, Northwest Providence and Santaren, as well as the Florida Current upstream of these two channels. On this basis the estimated total contribution from both channels is about $3 \mathrm{~Sv}$ (1.2 Sv from Northwest Providence and $1.8 \mathrm{~Sv}$ from Santaren).

Although only about $10 \%$ of the total Florida Current transport at $27^{\circ} \mathrm{N}$ [Leaman et al., 1987], this result nevertheless suggests that contributions from these two channels should not be ignored. This is particularly trus of the " $18^{\circ} \mathrm{C}$ " $\left(17.5^{\circ}-19.0^{\circ}\right)$ water, which can be relatively easily traced using these data. As described by Worthington [1976], $18^{\circ} \mathrm{C}$ water is formed in winter in a zone south of the Gulf Stream (to around $34^{\circ} \mathrm{N}$ ) in the northwestern Atlantic Ocean. The great thickness (small vertical temperature gradient) of this layer near its region of formation results in very low values of potential vorticity [Leaman et al., 1989]. It is important to keep in mind that if a layer of finite thickness (such as $17.5^{\circ} \mathrm{C}$ to $19.0^{\circ} \mathrm{C}$ ) is defined as the " $18^{\circ} \mathrm{C}$ layer," then any area of the ocean that has water in this temperature range will have some " $18^{\circ} \mathrm{C}$ water." For this reason, Worthington [1976] defined $18^{\circ} \mathrm{C}$ water as the excess of water in the " $18^{\circ} \mathrm{C}$ layer" compared to the amounts in layers immediately 
above and below. This excess is injected into the layer (with low potential vorticity) from the source region. As this water moves away from its source region, its low potential vorticity can (if this is assumed to be a conservative property) be used as a tracer [McCartney, 1982]. Other nonconservative effects (such as mixing) will smooth out the potential vorticity minimum as the water moves away from its source.

At $27^{\circ} \mathrm{N}$ the total average transport of this layer was about

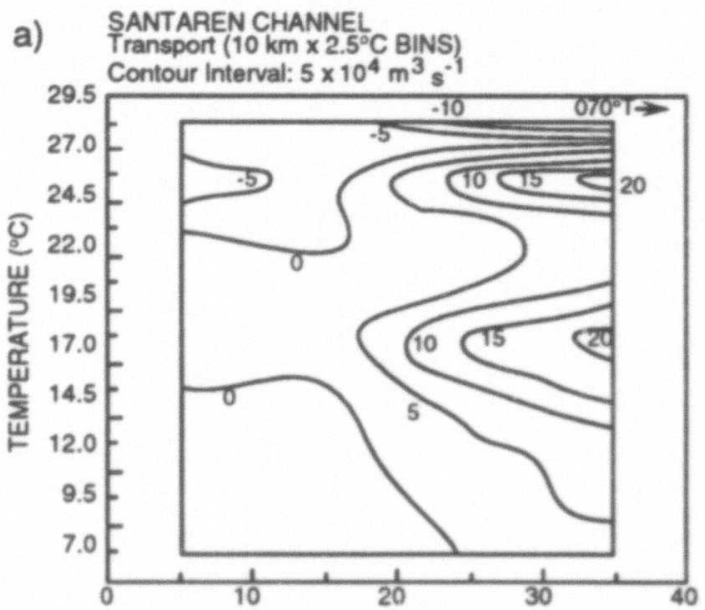

b) SANTAREN CHANNEL

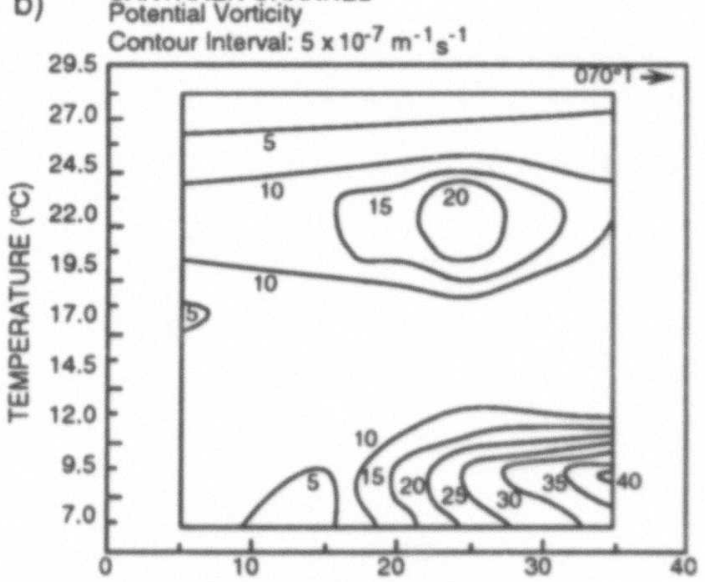

c) SANTAREN CHANNEL

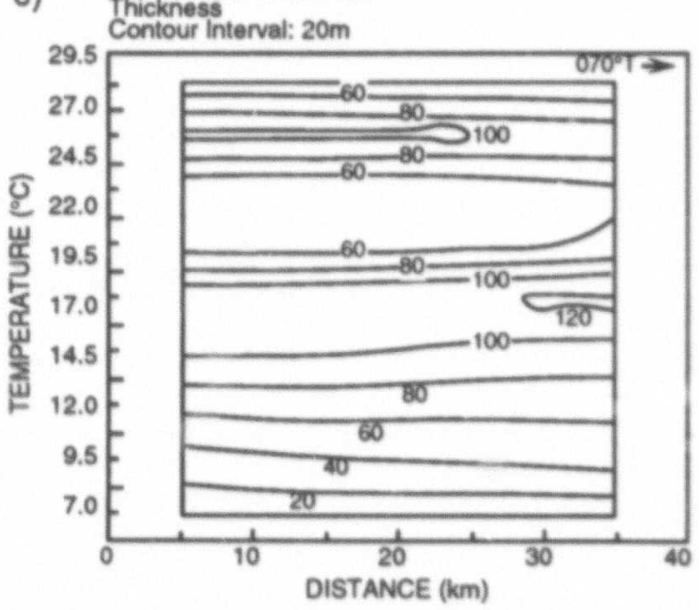

Figure 6. As in Figure 5, but for Santaren Channel.

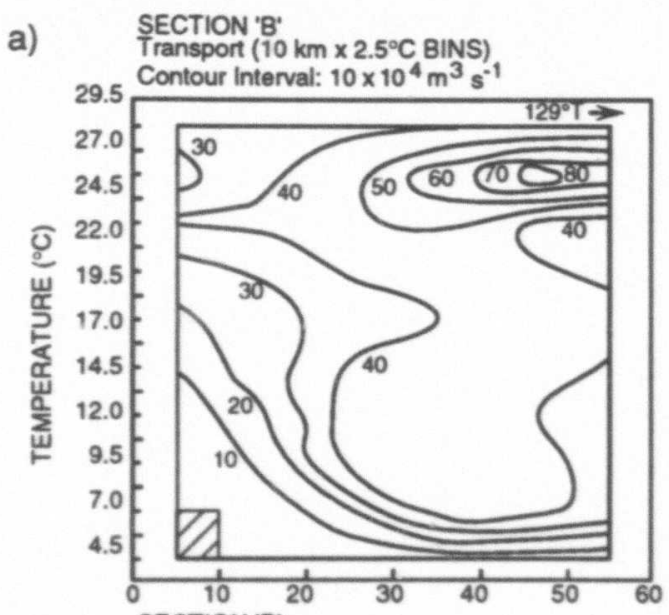

b)
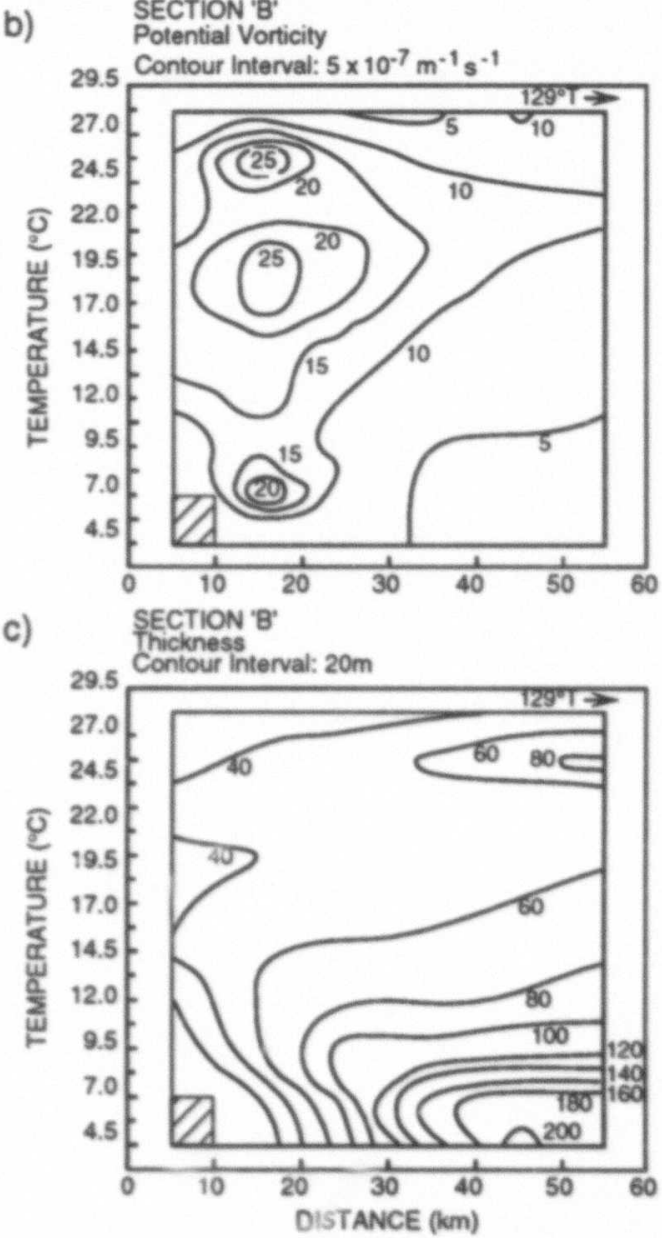

Figure 7. As in Figure 5, but for section "B" (Florida Current).

4.5 Sv; however, compared to layers immediately above and below, the "excess" $18^{\circ} \mathrm{C}$ water transported through $27^{\circ} \mathrm{N}$ is about 1.5 Sv [Leaman et al., 1989]. Using the annual average data from the sections discussed in this paper, $18^{\circ} \mathrm{C}$ transports are NWPC $=0.9 \mathrm{~Sv}, \mathrm{SC}=0.7 \mathrm{~Sv}$, and "B" $=2.4 \mathrm{~Sv}$ for a total of $4 \mathrm{~Sv}$, comparable to but about $1 / 2 \mathrm{~Sv}$ less than 
was found at $27^{\circ} \mathrm{N}$. (Note that these are $78 \%$ and $37 \%$ of the total transports found in NWPC and SC, respectively.)

It therefore appears that virtually all of the "excess" $18^{\circ} \mathrm{C}$ water can be accounted for by inflow from these two channels $(\sim 1.6 \mathrm{~Sv})$. This result is also supported by the layer potential vorticities. Only in NWPC is a significant amount of $18^{\circ} \mathrm{C}$ water found with low potential vorticity $\left(<5 \times 10^{-7}\right.$ $\left.\mathrm{m}^{-1} \mathrm{~s}^{-1}\right)$, comparable to values found on the eastern side of the Florida Current at $27^{\circ} \mathrm{N}$. In $\mathrm{SC} 18^{\circ} \mathrm{C}$ layer potential vorticities $\left(\times 10^{-7} \mathrm{~m}^{-1} \mathrm{~s}^{-1}\right)$ range from 4.6 (west) to 7.7 (middle), decreasing again to 5.2 (east), suggesting that the $18^{\circ} \mathrm{C}$ potential vorticity minimum has been reduced (possibly by mixing) before its arrival in SC. In contrast, there is no evidence for an $18^{\circ} \mathrm{C}$ potential vorticity minimum on section "B." Taken together, the above results suggest that most, if not all, of the $18^{\circ} \mathrm{C}$ water found at $27^{\circ} \mathrm{N}$ derives from inflow through NWPC and SC. Although this result appears to be at variance with Schmitz and Richardson [1991], who suggest that this $18^{\circ} \mathrm{C}$ water flows into the Caribbean via the Windward Passage, it should be kept in mind that the channels discussed here were not considered in these authors' analysis. Therefore our results suggest only that the pathway by which $18^{\circ} \mathrm{C}$ water arrives in the Straits of Florida may be different than they suggest, but otherwise does not alter significantly their conclusions. Also, there is a possibility that some $18^{\circ} \mathrm{C}$ water flows east along the Cuban coast through Nicholas Channel (where for other reasons it was impossible to make measurements) and then joins the flow in SC. However, the close agreement between mean transports computed for OBC (1.9 Sv [Atkinson et al., this issue]) and SC (1.8 Sv) argues that on average virtually all of the transport through OBC passes directly to the Florida Current via SC. The same is not the case for higher frequencies (periods $<\mathbf{5 0}$ days) however, for which little coherence is found between transport fluctuations in $\mathrm{OBC}$ and $\mathrm{SC}$ [ Lee et al., this issue].

The second $\mathrm{SC}$ transport peak in the $24.5^{\circ} \mathrm{C}-27.0^{\circ} \mathrm{C}$ temperature bin (Figure 6) is also of interest in that to within the somewhat crude resolution of the $2.5^{\circ} \mathrm{C}$ bins, one would expect to find subtropical underwater (STUW) within this range. Although the current profilers did not measure salinity, simultaneous conductivity-temperature-depth profiles clearly show the presence of the salinity tnaximum associated with STUW [Atkinson et al., this issue]. An earlier investigation [Wennekens, 1959] also showed the presence of this water (albeit intermittently) immediately to the west of Great Bahama Bank and to the north of SC. This layer is also only intermittently present in SC, in fact, only during the November 1990 section (when very high transports toward the Florida Current were present in SC) did this layer contribute a large percentage of the total SC transport. It is also clear that a similar high-transport layer is present on average up against Cay Sal Bank (Figure 7). Wennekens [1959] noted that a similar high-salinity layer (part of the "Yucatan Water") is present in the Gulf of Mexico. The origin of this layer in SC is not by any means clear. On the one hand, STUW is clearly present in OBC and should, based on the average transports, be advected into SC. On the other hand, the high transport observed in November 1990 may be associated with an offshore deflection of the Florida Current and diversion of transport through Nicholas Channel and into SC as suggested in by Lee et al. [this issue].
As a second result of these observations it was noted above that the peak layer vorticities seen in the cyclonicshear portion of the Florida Current on section "B" are roughly $5 \times 10^{-7} \mathrm{~m}^{-1} \mathrm{~s}^{-1}$ less than observed farther north (e.g., $29^{\circ} \mathrm{N}$ [Leaman et al., 1989]). It should be kept in mind that the layer potential vorticities as computed above do not include the curvature term, or $v / \mathbf{H r}$, where $v$ is tangential velocity, $\boldsymbol{H}$ is layer thickness, and $\boldsymbol{r}$ is radius of curvature. It is clear from Figures $4 a$ and $4 b$ that no single radius of curvature is appropriate for the whole Florida Current at section "B." However, in the region of peak layer potential vorticities in Figure $7 \mathrm{~b}$ layer thicknesses $(H)$ are about $50 \mathrm{~m}$ (Figure 7c). With a typical core velocity of $1.5 \mathrm{~m} \mathrm{~s}^{-1}$, a radius of curvature of about $50 \mathrm{~km}$ would be needed to provide the difference in layer potential vorticity given above. Qualitatively, this is probably not an unreasonable value given the sharp change in direction of topographic contours, particularly offshore of Pourtales Terrace (Figure 1).

Acknowledgments. We wish to thank the officers and crew of the University of Miami R/V Calanus for their assistance and for their ingenuity in attempting to keep the ship operational at sea under sometimes difficult conditions. We also thank Senior Marine Technician R. Jones and student S. Vaughan for their help at sea, and Froma Wlazlo for typing the manuscript. This work was supported by the Minerals Management Service under MMS contract 14-350001-30493.

\section{References}

Atkinson, L. P., T. Berger, P. Hamilton, E. Waddell, K. Leaman, and $\mathrm{T}$. Lee, Current meter observations in the Old Bahama Channel, J. Geophys. Res., this issue.

Brooks, I. H., Fluctuations in the transport of the Florida Current at periods between tidal and two weeks, J. Phys. Oceanogr., 9, 1048-1053, 1979.

Brooks, I. H., and P. P. Niiler, Energetics of the Florida Current, J. Mar. Res., 35, 163-191, 1977.

Halkin, D., and T. Rossby, The structure and transport of the Gulf Stream at $73^{\circ} \mathrm{W}, J$. Phys. Oceanogr., 15, 1439-1452, 1985.

Johns, W. E., and F. Schott, Meandering and transport variations of the Florida Current, J. Phys. Oceanogr., 17, 1128-1147, 1987.

Larsen, J. C., and T. B. Sanford, Florida Current volume transports from voltage measurements, Science, 227, 302-304, 1985.

Leaman, K. D., and R. L. Molinari, Topographic modification of the Florida Current by Little Bahama and Great Bahama Banks, $J$. Phys. Oceanogr., 17, 1724-1736, 1987.

Leaman, K. D., R. L. Molinari, and P. S. Vertes, Structure and variability of the Florida Current at $27^{\circ} \mathrm{N}$ : April 1982-July $1984, J$. Phys. Oceanogr., 17, 565-583, 1987.

Leaman, K. D., E. Johns, and T. Rossby, The average distribution of volume transport and potential vorticity with temperature at three sections across the Gulf Stream, J. Phys. Oceanogr., 19, $36-51,1989$.

Lee, T. N , and E. Williams, Wind forced transport fluctuations of the Florida Current, J. Phys. Oceanogr., 18, 937-946, 1988.

Lee, T. N., F. A. Schott, and R. J. Zantopp, Florida Current: Low-frequency variability as observed with moored current meters during April 1982 to June 1983, Science, 227, 298-302, 1985.

Lee, T. N., K. Leaman, E. Williams, T. Berger, and L. Atkinson, Florida Current meanders and gyre formation in the southern Straits of Florida, J. Geophys. Res., this issue.

Maul, G. A., F. Chew, M. Bushnell, and D. A. Mayer, Sea level variations as an indicator of Florida Current volume transport: Comparisons with direct measurements, Science, 227, 304-307, 1985.

Mayer, D. A., K. D. Leaman, and T. N. Lee, Tidal motions in the Florida Current, J. Phys. Oceanogr., 14, 1551-1559, 1984.

McCartney, M. S., The subtropical recirculation of mode waters, $J$. Mar. Res., 40, suppl., 427-464, 1982. 
Molinari, R. L., STACS: Subtropical Atlantic Climate Studies, Eos Trans. $A G U, 64,2,1983$.

Molinari, R. L., et al., Subtropical Atlantic Climate Studies: Introduction, Science, 227, 292-295, 1985a.

Molinari, R. L., W. D. Wilson, and K. D. Leaman, Volume and heat transports of the Florida Current: April 1982 through August 1983. Science, 227, 292-295, 1985b.

Niiler, P. P., and W. S. Richardson, Seasonal variability in the Florida Current, J. Mar. Res., 21, 144-167, 1973.

Richardson, W. S., and J. R. Finlen, The transport of Northwest Providence Channel, Deep Sea Res., 14, 361-367, 1967.

Richardson, W. S., W. J. Schmitz, and P. P. Niiler, The velocity structure of the Florida Current from the Straits of Florida to Cape Fear, Deep Sea Res., 16, 225-234, 1969.

Schmitz, W. J., and P. L. Richardson, On the sources of the Florida Current, Deep Sea Res., 38, suppl. 1, 5379-5409, 1991.

Schmitz, W. J., and W. S. Richardson, On the transport of the Florida Current, Deep Sea Res., 15, 679-693, 1968.

Schott, F. A., and R. J. Zantopp, Florida Current: Seasonal and interannual variability, Science, 227, 308-311, 1985.

Schott, F. A., T. N. Lee, and R. J. Zantopp, Variability of structure and transport of the Florida Current in the period range of days to seasonal, J. Phys. Oceanogr., 18, 1209-1230, 1988.

Science Applications International Corporation (SAIC), Straits of
Florida physical oceanographic field study, draft final interpretive report, vol. II, Technical report, Rep. OCS Study 920024,174 pp., Raleigh, N. C., 1992.

Smith, C. L.. The Great Bahama Bank, I, General hydrographical and chemical features, J. Mar. Res., 3, 147-170, 1940.

Wennekens, M. P., Water mass properties of the Straits of Florida and related waters, Bull. Mar. Sci., 9(I), 1-47, 1959.

Worthington, L. V., On the North Atlantic Circulation, Johns Hopkins Oceanogr. Stud., 6, 85-91, 1976.

L. P. Atkinson, Center for Coastal Physical Oceanography, Old Dominion University, 768 52nd Street, Norfolk, VA 23529. (e-mail: l:atkinson@ccpo.odu.edu)

P. Hamilton and E. Waddell, Science Applications International Corporation, 615 Oberlin Road, Raleigh, NC 27605.

K. D. Leaman, T. N. Lee, and P. S. Vertes, University of Miami Rosenstiel School of Marine and Atmospheric Science, 4600 Rickenbacker Causeway, Miami, FL 33149-1098. (e-mail: kleaman@rsmas. miami.edu; tlee@rsmas.miami.edu; pvertes@rsmas.miami.edu)

(Received March 25, 1993; revised March 7, 1994; accepted May 6, 1994.) 